\title{
A New Type of Cemented Sand-Gravel (CSG) Mixtures for Water-Tightening of Hardfill Dams
}

\section{Sina Karimi}

Azarbaijan Shahid Madani University

Hamed Farshbaf Aghajani ( $\sim$ h.farshbaf@azaruniv.ac.ir)

Azarbaijan Shahid Madani University https://orcid.org/0000-0003-2559-7520

\section{Research Article}

Keywords: Hardfill dam, Cemented sand and gravel (CSG) mixture, Bentonite additive, Kaolinite additive, permeability

Posted Date: December 1st, 2021

DOI: https://doi.org/10.21203/rs.3.rs-476303/v1

License: @ (i) This work is licensed under a Creative Commons Attribution 4.0 International License. Read Full License 


\section{Abstract}

This paper aims to achieve a specific type of cemented sand-gravel mixtures with low permeability to implement in the impervious zone of hardfill dams. To this end, various mixtures are prepared by blending two native soils of sand and gravel with different amounts of kaolinite or bentonite additives in presence of various cement content. The compaction properties, uniaxial compressive strength, permeability and scanning electron microscope (SEM) images of mixtures are measured. According to the results, the cemented mixture containing $10 \%$ of kaolinite additive regardless of native soil type exhibits the maximum strength. However, the bentonite disturbs the cement hydration in the mixture, and the strength of mixtures especially with high cement content decreases with increasing the bentonite content. The permeability of mixtures is related to the amount of cement and fine additive in the mixture. The permeability of both cemented sand and gravel mixtures decreases with increasing the bentonite additive. However, the kaolinite additive has a limited influence on the permeability of cemented gravel mixtures. The lowest permeability is achieved in the mixture involving the higher amount of bentonite (with a weight ratio of $30 \%$ ) in presence of adequate cement.

\section{1- Introduction}

The cemented sand-gravel (CSG) mixtures are widely used for fast and economical construction of embankments such as hardfill dams. The material used in hardfill dams is mainly provided by blending coarse-grained soils and cement agents in the presence of low water content and, then the dam body is constructed by progressive spreading and compaction of the mixture with heavy-duty compaction rollers (Yokotsuka 2000). The first idea of a hardfill dam was proposed by Londe and Lino (1992). Since the last two decades, the hardfill dams have been developed as a new solution for the construction of embankment dams with regrading to many advantages (Cai et al. 2012; Jia et al. 2016). Numerous hardfill dams were constructed in the world by using the cemented sand-gravel mixtures (Yokotsuka 2000; Batmaz 2003; GUILLEMOT and LINO 2012). The cemented material dam (CMD) is the latest solution for the hardfill dams, where the cement is blended with low quality soil aggregates to produce the cemented material (Jia et al. 2020).

One of the most key issues about the hardfill dams is how to deal with the impervious element in the dam body. The most practical method for water tightening of hardfill dam is construction of an impervious layer on the upstream face of the dam. Commonly, the upstream impervious face is made of conventional concrete with higher cement content (GUILLEMOT and LINO 2012), geomembrane (Gouvas and Orfanos 2014), precast concrete slabs (Yanmaz and Sezgin 2009), or other impervious material. However, the difference in strength and stiffness properties between the main hardfill dam body and impervious element, especially in the case of conventional concrete, may impose the non-uniformity in settlement and even leads to cracks in the rigid upstream face. Besides, in most of the aforementioned cases, the upstream impervious face should be constructed after completing the dam body (Gouvas and Orfanos 2014) and this can be time-consuming. Also, some specific procedures are required for connecting the upstream face to the main body of the hardfill dam. For overcoming these disadvantages, the most effective solution for the impervious upstream face of the hardfill dam is using a specific type of soil-cement mixture that has very low permeability and owns analogous properties with the hardfill dam body. With this solution, the construction of both the upstream face and the main body of the hardfill dam can be simultaneously done in the same stages with a similar 
procedure which saves time and costs. One solution for attaining the low permeable type of cemented sandgravel mixture is adding fine-grained materials such as bentonite or kaolinite powders to the mixture.

The early studies about the permeability of soil-cement mixtures focused on the plastic concrete, which consisted of similar material with soil-cement mixture and used in the cutoff wall of dams (Álvarez 1982; Shuttoh 1983; Yu et al. 1997). Yu et al. (1999) studied the effects of the confinement on the permeability of hollow cylindrical specimens of soil-cement mixture under various levels of shear stress. The results showed that the permeability of soil-cement specimens is related to the confining pressure and vertical loads. Mahasneh and Shawabkeh (2004) investigated the permeability and strength of various admixtures of sandclay-cement. According to their results, the mixture comprised of $25 \%$ of sand, $50 \%$ of cement, and $25 \%$ of clay owns the maximum strength with comparatively less permeability. Besides, sample involving $25 \%$ of sand and $75 \%$ of cement without clay has the maximum compressive strength.

Bellezza and Fratalocchi (2006) examined the permeability and compaction properties of soil-cement mixtures at the curing age of 25 days. The mixtures involve various types of soil from sand to clay and $5 \%$ of cement. They concluded that the permeability of all mixtures with $5 \%$ cement was obtained less than $2 \times 10^{-7}$ $\mathrm{cm} / \mathrm{s}$. Yongfeng et al. (2012) measured the permeability and compressive strength of marine clay-cement mixtures that are enriched with a polymer. The mixtures contained cement with the weight ratio of 3,5 and $7 \%$. The test results implied that increasing cement in mixtures leads to a decrease in permeability of mixtures. Besides, the polymer additive increases the failure strain and deformability of mixtures. According to the experiments of Jamshidi and Lake (2015), when the soil-cement mixtures are subjected to the freezingthawing cycles, the hydraulic conductivity increases. In similar research, Lake et al. (2017) investigate the performance and morphology of soil-cement mixtures with low cement content under freezing-thawing cycles. According to the permeability test results, increasing in the permeability of mixtures after sequences of freezing-thawing cycles may be due to emerging new cracks in the material and some new ice lens remain inside the mixture.

Even though conducting the previous studies about the permeability of cemented sand-gravel mixtures, there is a lack of systematic investigation about the permeability and strength of coarse-grained soil-cement admixtures which are blended with various amounts of fine-grained soils with low and high plasticity specifications. The current research investigates the compaction, uniaxial compressive strength and permeability of cemented sand and cemented gravel mixtures which are enriched with the fine-grained particles of bentonite and kaolinite.

\section{2- Testing Material}

In this study, two natural coarse-grained soils with the same origin are used as the native soil in mixtures which are retrieved from a location at the latitude of $37.810100^{\circ}$ and the longitude of $45.945064^{\circ}$. The first native soil is a poor graded sandy gravel and denoted by " $G$ " soil. The G soil is comprised of $63 \%$ gravel and $36 \%$ sand. The second native soil is sand which is comprised of $57 \%$ sand and $42 \%$ gravel and called the $S$ soil. The $\mathrm{G}$ and $\mathrm{S}$ soils are classified as the GP and SW groups in the unified soil classification system (USCS), respectively. Both native soils of $\mathrm{G}$ and $\mathrm{S}$ have originally fine content (passing through the \#200 sieve) less 
than $1 \%$. The particle size distribution of native soils is shown in Fig. 1. Other specifications of soils of $\mathrm{G}$ and S are presented in Table 1.

Table 1

The specifications of native soil (S) and fine additives (kaolinite and bentonite)

\begin{tabular}{|lllll|}
\hline & $\begin{array}{l}\text { Sand soil } \\
(\mathbf{S})\end{array}$ & $\begin{array}{l}\text { Gravel soil } \\
(\mathbf{G})\end{array}$ & $\begin{array}{l}\text { Kaolinite additive } \\
(\mathbf{K})\end{array}$ & $\begin{array}{l}\text { Bentonite additive } \\
\text { (B) }\end{array}$ \\
\hline Specific gravity (Gs) & 2.65 & 2.69 & 2.65 & 2.79 \\
\hline Unified soil classification & SW & GP & & 160.9 \\
\hline Liquid limit (\%) & NP & NP & 45 & 114.2 \\
\hline Plastic index (\%) & NP & NP & 19 & 0.045 \\
\hline $\begin{array}{l}\text { D } \text { max (mm) } \\
\text { Maximum dry density }\end{array}$ & 19 & 19 & 0.15 & 11.5 \\
\hline kN/m ${ }^{3}$ ) & 18.11 & 17.85 & 16.5 & 39 \\
\hline Optimum water content $(\%)$ & 8.55 & 7.51 & 18 & \\
\hline
\end{tabular}

Two fine grained additives of kaolinite (denoted by K) and bentonite (denoted by B) are separately blended with each native soil ( $S$ and $G$ soils) to introduce various base soils that are used in the cemented mixture. The white powder of bentonite additive is supplied from the factory of Iran Barit Falat Co. and predominantly comprised of montmorillonite mineral. The bentonite has high plastic index of $114 \%$. The specifications of the bentonite additive are presented in Table 1. The kaolinite additive is a production from Iran china Clay Industries Company and the plastic limit, liquid limit and plastic index are presented in Table 1. The maximum dry density and optimum water content of both native soils and two additives are measured in accordance with the ASTM D 698 standard (ASTM 2012) and presented in Table 1.

The Ordinary Portland type II cement is used as the cementation agent in cemented mixtures which is supplied from the Sufian Cement Company (SCC) located in North West of Iran and has the blaine value of 3049 $\left(\mathrm{cm}^{2} / \mathrm{gr}\right)$ and initial and final setting time of 116 and 175 minutes, respectively. The mineral composition of cement powder is presented in Table 2.

Table 2

The chemical composition (in percent) of cement agent used in mixtures

\begin{tabular}{|llllll|}
\hline $\mathrm{Si}_{2} \mathrm{O}$ & $\mathrm{Al}_{2} \mathrm{O}_{3}$ & $\mathrm{Fe}_{2} \mathrm{O}_{3}$ & $\mathrm{CaO}$ & $\mathrm{MgO}$ & $\mathrm{SO}_{3}$ \\
\hline 21.7 & 4.7 & 3.6 & 63.6 & 3.4 & 2.9 \\
\hline
\end{tabular}

\section{3- Testing Program And Procedure}

In the current research, the compaction, uniaxial compressive strength and permeability of cemented sand and cemented gravel mixtures enriched with fine-grained additives are studied. To this end, different base soils are 
prepared by blending each native soil with a different amount of kaolinite or bentonite additives. Then, the cement agent with a weight content of 5,10 and $15 \%$ is added to each base soil to produce the soil-cement mixtures. The cement content in mixtures is expressed as the ratio of cement weight to the dry weight of base soil (including a summation of native soil and fine additive). Moreover, the fine content in the mixture refers to the dry weight ratio of fine-grained additive to the native soil and is selected as $0,10,20$ and $30 \%$. With the mentioned range of cement and fine additive contents, 21 mixture designations are prepared with each native soil of sand and gravel which are presented in Table 3 and Table 4, respectively. 
Table 3

The designation of cemented sand mixtures and testing program

\begin{tabular}{|c|c|c|c|c|c|c|c|}
\hline $\begin{array}{l}\text { Mixture } \\
\text { designation }\end{array}$ & $\begin{array}{l}\text { Cement } \\
\text { content } \\
(\%)\end{array}$ & $\begin{array}{l}\text { Additive } \\
\text { type }\end{array}$ & $\begin{array}{l}\text { Additive } \\
\text { content } \\
(\%)\end{array}$ & $\begin{array}{l}\text { Compaction } \\
\text { test }\end{array}$ & $\begin{array}{l}\text { Uniaxial } \\
\text { compressive } \\
\text { test }\end{array}$ & $\begin{array}{l}\text { Permeability } \\
\text { test }\end{array}$ & $\begin{array}{l}\text { SEM } \\
\text { imaging }\end{array}$ \\
\hline S-C5 & 5 & - & 0 & $\begin{array}{l}\text { fresh } \\
\text { state }\end{array}$ & $\begin{array}{l}\text { at curing } \\
\text { ages of } 7 \\
\text { and } 28 \text { days }\end{array}$ & $\begin{array}{l}\text { at curing } \\
\text { ages of } 14 \\
\text { and } 28 \text { days }\end{array}$ & $\begin{array}{l}\text { at } \\
\text { curing } \\
\text { age of } \\
28 \text { days }\end{array}$ \\
\hline S-C10 & 10 & - & 0 & $\begin{array}{l}\text { fresh } \\
\text { state }\end{array}$ & $\begin{array}{l}\text { at curing } \\
\text { ages of } 7 \\
\text { and } 28 \text { days }\end{array}$ & $\begin{array}{l}\text { at curing } \\
\text { ages of } 14 \\
\text { and } 28 \text { days }\end{array}$ & $\begin{array}{l}\text { at } \\
\text { curing } \\
\text { age of } \\
28 \text { days }\end{array}$ \\
\hline S-C15 & 15 & - & 0 & $\begin{array}{l}\text { fresh } \\
\text { state }\end{array}$ & $\begin{array}{l}\text { at curing } \\
\text { ages of } 7 \\
\text { and } 28 \text { days }\end{array}$ & $\begin{array}{l}\text { at curing } \\
\text { ages of } 14 \\
\text { and } 28 \text { days }\end{array}$ & $\begin{array}{l}\text { at } \\
\text { curing } \\
\text { age of } \\
28 \text { days }\end{array}$ \\
\hline S-C5-K10 & 5 & kaolinite & 10 & $\begin{array}{l}\text { fresh } \\
\text { state }\end{array}$ & $\begin{array}{l}\text { at curing } \\
\text { ages of } 7 \\
\text { and } 28 \text { days }\end{array}$ & $\begin{array}{l}\text { at curing } \\
\text { ages of } 14 \\
\text { and } 28 \text { days }\end{array}$ & $\begin{array}{l}\text { at } \\
\text { curing } \\
\text { age of } \\
28 \text { days }\end{array}$ \\
\hline S-C5-K20 & 5 & kaolinite & 20 & $\begin{array}{l}\text { fresh } \\
\text { state }\end{array}$ & $\begin{array}{l}\text { at curing } \\
\text { ages of } 7 \\
\text { and } 28 \text { days }\end{array}$ & $\begin{array}{l}\text { at curing } \\
\text { ages of } 14 \\
\text { and } 28 \text { days }\end{array}$ & $\begin{array}{l}\text { at } \\
\text { curing } \\
\text { age of } \\
28 \text { days }\end{array}$ \\
\hline S-C5-K30 & 5 & kaolinite & 30 & $\begin{array}{l}\text { fresh } \\
\text { state }\end{array}$ & $\begin{array}{l}\text { at curing } \\
\text { ages of } 7 \\
\text { and } 28 \text { days }\end{array}$ & $\begin{array}{l}\text { at curing } \\
\text { ages of } 14 \\
\text { and } 28 \text { days }\end{array}$ & $\begin{array}{l}\text { at } \\
\text { curing } \\
\text { age of } \\
28 \text { days }\end{array}$ \\
\hline S-C5-B10 & 5 & bentonite & 10 & $\begin{array}{l}\text { fresh } \\
\text { state }\end{array}$ & $\begin{array}{l}\text { at curing } \\
\text { ages of } 7 \\
\text { and } 28 \text { days }\end{array}$ & $\begin{array}{l}\text { at curing } \\
\text { ages of } 14 \\
\text { and } 28 \text { days }\end{array}$ & $\begin{array}{l}\text { at } \\
\text { curing } \\
\text { age of } \\
28 \text { days }\end{array}$ \\
\hline S-C5-B20 & 5 & bentonite & 20 & $\begin{array}{l}\text { fresh } \\
\text { state }\end{array}$ & $\begin{array}{l}\text { at curing } \\
\text { ages of } 7 \\
\text { and } 28 \text { days }\end{array}$ & $\begin{array}{l}\text { at curing } \\
\text { ages of } 14 \\
\text { and } 28 \text { days }\end{array}$ & $\begin{array}{l}\text { at } \\
\text { curing } \\
\text { age of } \\
28 \text { days }\end{array}$ \\
\hline S-C5-B30 & 5 & bentonite & 30 & $\begin{array}{l}\text { fresh } \\
\text { state }\end{array}$ & $\begin{array}{l}\text { at curing } \\
\text { ages of } 7 \\
\text { and } 28 \text { days }\end{array}$ & $\begin{array}{l}\text { at curing } \\
\text { ages of } 14 \\
\text { and } 28 \text { days }\end{array}$ & $\begin{array}{l}\text { at } \\
\text { curing } \\
\text { age of } \\
28 \text { days }\end{array}$ \\
\hline S-C10-K10 & 10 & kaolinite & 10 & $\begin{array}{l}\text { fresh } \\
\text { state }\end{array}$ & $\begin{array}{l}\text { at curing } \\
\text { ages of } 7 \\
\text { and } 28 \text { days }\end{array}$ & $\begin{array}{l}\text { at curing } \\
\text { ages of } 14 \\
\text { and } 28 \text { days }\end{array}$ & - \\
\hline S-C10-K20 & 10 & kaolinite & 20 & $\begin{array}{l}\text { fresh } \\
\text { state }\end{array}$ & $\begin{array}{l}\text { at curing } \\
\text { ages of } 7 \\
\text { and } 28 \text { days }\end{array}$ & $\begin{array}{l}\text { at curing } \\
\text { ages of } 14 \\
\text { and } 28 \text { days }\end{array}$ & - \\
\hline
\end{tabular}




\begin{tabular}{|c|c|c|c|c|c|c|c|}
\hline $\begin{array}{l}\text { Mixture } \\
\text { designation }\end{array}$ & $\begin{array}{l}\text { Cement } \\
\text { content } \\
(\%)\end{array}$ & $\begin{array}{l}\text { Additive } \\
\text { type }\end{array}$ & $\begin{array}{l}\text { Additive } \\
\text { content } \\
\text { (\%) }\end{array}$ & $\begin{array}{l}\text { Compaction } \\
\text { test }\end{array}$ & $\begin{array}{l}\text { Uniaxial } \\
\text { compressive } \\
\text { test }\end{array}$ & $\begin{array}{l}\text { Permeability } \\
\text { test }\end{array}$ & $\begin{array}{l}\text { SEM } \\
\text { imaging }\end{array}$ \\
\hline S-C10-K30 & 10 & kaolinite & 30 & $\begin{array}{l}\text { fresh } \\
\text { state }\end{array}$ & $\begin{array}{l}\text { at curing } \\
\text { ages of } 7 \\
\text { and } 28 \text { days }\end{array}$ & $\begin{array}{l}\text { at curing } \\
\text { ages of } 14 \\
\text { and } 28 \text { days }\end{array}$ & - \\
\hline S-C10-B10 & 10 & bentonite & 10 & $\begin{array}{l}\text { fresh } \\
\text { state }\end{array}$ & $\begin{array}{l}\text { at curing } \\
\text { ages of } 7 \\
\text { and } 28 \text { days }\end{array}$ & $\begin{array}{l}\text { at curing } \\
\text { ages of } 14 \\
\text { and } 28 \text { days }\end{array}$ & - \\
\hline S-C10-B20 & 10 & bentonite & 20 & $\begin{array}{l}\text { fresh } \\
\text { state }\end{array}$ & $\begin{array}{l}\text { at curing } \\
\text { ages of } 7 \\
\text { and } 28 \text { days }\end{array}$ & $\begin{array}{l}\text { at curing } \\
\text { ages of } 14 \\
\text { and } 28 \text { days }\end{array}$ & - \\
\hline S-C10-B30 & 10 & bentonite & 30 & $\begin{array}{l}\text { fresh } \\
\text { state }\end{array}$ & $\begin{array}{l}\text { at curing } \\
\text { ages of } 7 \\
\text { and } 28 \text { days }\end{array}$ & $\begin{array}{l}\text { at curing } \\
\text { ages of } 14 \\
\text { and } 28 \text { days }\end{array}$ & - \\
\hline S-C15-K10 & 15 & kaolinite & 10 & $\begin{array}{l}\text { fresh } \\
\text { state }\end{array}$ & $\begin{array}{l}\text { at curing } \\
\text { ages of } 7 \\
\text { and } 28 \text { days }\end{array}$ & $\begin{array}{l}\text { at curing } \\
\text { ages of } 14 \\
\text { and } 28 \text { days }\end{array}$ & \\
\hline S-C15-K20 & 15 & kaolinite & 20 & $\begin{array}{l}\text { fresh } \\
\text { state }\end{array}$ & $\begin{array}{l}\text { at curing } \\
\text { ages of } 7 \\
\text { and } 28 \text { days }\end{array}$ & $\begin{array}{l}\text { at curing } \\
\text { ages of } 14 \\
\text { and } 28 \text { days }\end{array}$ & \\
\hline S-C15-K30 & 15 & kaolinite & 30 & $\begin{array}{l}\text { fresh } \\
\text { state }\end{array}$ & $\begin{array}{l}\text { at curing } \\
\text { ages of } 7 \\
\text { and } 28 \text { days }\end{array}$ & $\begin{array}{l}\text { at curing } \\
\text { ages of } 14 \\
\text { and } 28 \text { days }\end{array}$ & \\
\hline S-C15-B10 & 15 & bentonite & 10 & $\begin{array}{l}\text { fresh } \\
\text { state }\end{array}$ & $\begin{array}{l}\text { at curing } \\
\text { ages of } 7 \\
\text { and } 28 \text { days }\end{array}$ & $\begin{array}{l}\text { at curing } \\
\text { ages of } 14 \\
\text { and } 28 \text { days }\end{array}$ & \\
\hline S-C15-B20 & 15 & bentonite & 20 & $\begin{array}{l}\text { fresh } \\
\text { state }\end{array}$ & $\begin{array}{l}\text { at curing } \\
\text { ages of } 7 \\
\text { and } 28 \text { days }\end{array}$ & $\begin{array}{l}\text { at curing } \\
\text { ages of } 14 \\
\text { and } 28 \text { days }\end{array}$ & \\
\hline S-C15-B30 & 15 & bentonite & 30 & $\begin{array}{l}\text { fresh } \\
\text { state }\end{array}$ & $\begin{array}{l}\text { at curing } \\
\text { ages of } 7 \\
\text { and } 28 \text { days }\end{array}$ & $\begin{array}{l}\text { at curing } \\
\text { ages of } 14 \\
\text { and } 28 \text { days }\end{array}$ & \\
\hline
\end{tabular}


Table 4

The designation of cemented gravel mixtures and testing program

\begin{tabular}{|c|c|c|c|c|c|c|}
\hline $\begin{array}{l}\text { Mixture } \\
\text { designation }\end{array}$ & $\begin{array}{l}\text { Cement } \\
\text { content (\%) }\end{array}$ & $\begin{array}{l}\text { Additive } \\
\text { type }\end{array}$ & $\begin{array}{l}\text { Additive } \\
\text { content (\%) }\end{array}$ & $\begin{array}{l}\text { Compaction } \\
\text { test }\end{array}$ & $\begin{array}{l}\text { Uniaxial } \\
\text { compressive test }\end{array}$ & $\begin{array}{l}\text { Permeability } \\
\text { test }\end{array}$ \\
\hline G-C5 & 5 & - & 0 & $\begin{array}{l}\text { fresh } \\
\text { state }\end{array}$ & $\begin{array}{l}\text { at curing ages of } \\
7 \text { and } 28 \text { days }\end{array}$ & $\begin{array}{l}\text { at curing } \\
\text { age of } 28 \\
\text { days }\end{array}$ \\
\hline G -C10 & 10 & - & 0 & $\begin{array}{l}\text { fresh } \\
\text { state }\end{array}$ & $\begin{array}{l}\text { at curing ages of } \\
7 \text { and } 28 \text { days }\end{array}$ & $\begin{array}{l}\text { at curing } \\
\text { age of } 28 \\
\text { days }\end{array}$ \\
\hline G -C15 & 15 & - & 0 & $\begin{array}{l}\text { fresh } \\
\text { state }\end{array}$ & $\begin{array}{l}\text { at curing ages of } \\
7 \text { and } 28 \text { days }\end{array}$ & $\begin{array}{l}\text { at curing } \\
\text { age of } 28 \\
\text { days }\end{array}$ \\
\hline G -C5-K10 & 5 & kaolinite & 10 & $\begin{array}{l}\text { fresh } \\
\text { state }\end{array}$ & $\begin{array}{l}\text { at curing ages of } \\
7 \text { and } 28 \text { days }\end{array}$ & $\begin{array}{l}\text { at curing } \\
\text { age of } 28 \\
\text { days }\end{array}$ \\
\hline G -C5-K20 & 5 & kaolinite & 20 & $\begin{array}{l}\text { fresh } \\
\text { state }\end{array}$ & $\begin{array}{l}\text { at curing ages of } \\
7 \text { and } 28 \text { days }\end{array}$ & $\begin{array}{l}\text { at curing } \\
\text { age of } 28 \\
\text { days }\end{array}$ \\
\hline G -C5-K30 & 5 & kaolinite & 30 & $\begin{array}{l}\text { fresh } \\
\text { state }\end{array}$ & $\begin{array}{l}\text { at curing ages of } \\
7 \text { and } 28 \text { days }\end{array}$ & $\begin{array}{l}\text { at curing } \\
\text { age of } 28 \\
\text { days }\end{array}$ \\
\hline G -C5-B10 & 5 & bentonite & 10 & $\begin{array}{l}\text { fresh } \\
\text { state }\end{array}$ & $\begin{array}{l}\text { at curing ages of } \\
7 \text { and } 28 \text { days }\end{array}$ & $\begin{array}{l}\text { at curing } \\
\text { age of } 28 \\
\text { days }\end{array}$ \\
\hline G -C5-B20 & 5 & bentonite & 20 & $\begin{array}{l}\text { fresh } \\
\text { state }\end{array}$ & $\begin{array}{l}\text { at curing ages of } \\
7 \text { and } 28 \text { days }\end{array}$ & $\begin{array}{l}\text { at curing } \\
\text { age of } 28 \\
\text { days }\end{array}$ \\
\hline G -C5-B30 & 5 & bentonite & 30 & $\begin{array}{l}\text { fresh } \\
\text { state }\end{array}$ & $\begin{array}{l}\text { at curing ages of } \\
7 \text { and } 28 \text { days }\end{array}$ & $\begin{array}{l}\text { at curing } \\
\text { age of } 28 \\
\text { days }\end{array}$ \\
\hline G -C10-K10 & 10 & kaolinite & 10 & $\begin{array}{l}\text { fresh } \\
\text { state }\end{array}$ & $\begin{array}{l}\text { at curing ages of } \\
7 \text { and } 28 \text { days }\end{array}$ & $\begin{array}{l}\text { at curing } \\
\text { age of } 28 \\
\text { days }\end{array}$ \\
\hline G -C10-K20 & 10 & kaolinite & 20 & $\begin{array}{l}\text { fresh } \\
\text { state }\end{array}$ & $\begin{array}{l}\text { at curing ages of } \\
7 \text { and } 28 \text { days }\end{array}$ & $\begin{array}{l}\text { at curing } \\
\text { age of } 28 \\
\text { days }\end{array}$ \\
\hline G -C10-K30 & 10 & kaolinite & 30 & $\begin{array}{l}\text { fresh } \\
\text { state }\end{array}$ & $\begin{array}{l}\text { at curing ages of } \\
7 \text { and } 28 \text { days }\end{array}$ & $\begin{array}{l}\text { at curing } \\
\text { age of } 28 \\
\text { days }\end{array}$ \\
\hline G -C10-B10 & 10 & bentonite & 10 & $\begin{array}{l}\text { fresh } \\
\text { state }\end{array}$ & $\begin{array}{l}\text { at curing ages of } \\
7 \text { and } 28 \text { days }\end{array}$ & $\begin{array}{l}\text { at curing } \\
\text { age of } 28 \\
\text { days }\end{array}$ \\
\hline G -C10-B20 & 10 & bentonite & 20 & $\begin{array}{l}\text { fresh } \\
\text { state }\end{array}$ & $\begin{array}{l}\text { at curing ages of } \\
7 \text { and } 28 \text { days }\end{array}$ & $\begin{array}{l}\text { at curing } \\
\text { age of } 28 \\
\text { days }\end{array}$ \\
\hline
\end{tabular}




\begin{tabular}{|c|c|c|c|c|c|c|}
\hline $\begin{array}{l}\text { Mixture } \\
\text { designation }\end{array}$ & $\begin{array}{l}\text { Cement } \\
\text { content (\%) }\end{array}$ & $\begin{array}{l}\text { Additive } \\
\text { type }\end{array}$ & $\begin{array}{l}\text { Additive } \\
\text { content (\%) }\end{array}$ & $\begin{array}{l}\text { Compaction } \\
\text { test }\end{array}$ & $\begin{array}{l}\text { Uniaxial } \\
\text { compressive test }\end{array}$ & $\begin{array}{l}\text { Permeability } \\
\text { test }\end{array}$ \\
\hline G -C10-B30 & 10 & bentonite & 30 & $\begin{array}{l}\text { fresh } \\
\text { state }\end{array}$ & $\begin{array}{l}\text { at curing ages of } \\
7 \text { and } 28 \text { days }\end{array}$ & $\begin{array}{l}\text { at curing } \\
\text { age of } 28 \\
\text { days }\end{array}$ \\
\hline G -C15-K10 & 15 & kaolinite & 10 & $\begin{array}{l}\text { fresh } \\
\text { state }\end{array}$ & $\begin{array}{l}\text { at curing ages of } \\
7 \text { and } 28 \text { days }\end{array}$ & $\begin{array}{l}\text { at curing } \\
\text { age of } 28 \\
\text { days }\end{array}$ \\
\hline G -C15-K20 & 15 & kaolinite & 20 & $\begin{array}{l}\text { fresh } \\
\text { state }\end{array}$ & $\begin{array}{l}\text { at curing ages of } \\
7 \text { and } 28 \text { days }\end{array}$ & $\begin{array}{l}\text { at curing } \\
\text { age of } 28 \\
\text { days }\end{array}$ \\
\hline G -C15-K30 & 15 & kaolinite & 30 & $\begin{array}{l}\text { fresh } \\
\text { state }\end{array}$ & $\begin{array}{l}\text { at curing ages of } \\
7 \text { and } 28 \text { days }\end{array}$ & $\begin{array}{l}\text { at curing } \\
\text { age of } 28 \\
\text { days }\end{array}$ \\
\hline G -C15-B10 & 15 & bentonite & 10 & $\begin{array}{l}\text { fresh } \\
\text { state }\end{array}$ & $\begin{array}{l}\text { at curing ages of } \\
7 \text { and } 28 \text { days }\end{array}$ & $\begin{array}{l}\text { at curing } \\
\text { age of } 28 \\
\text { days }\end{array}$ \\
\hline G -C15-B20 & 15 & bentonite & 20 & $\begin{array}{l}\text { fresh } \\
\text { state }\end{array}$ & $\begin{array}{l}\text { at curing ages of } \\
7 \text { and } 28 \text { days }\end{array}$ & $\begin{array}{l}\text { at curing } \\
\text { age of } 28 \\
\text { days }\end{array}$ \\
\hline G -C15-B30 & 15 & bentonite & 30 & $\begin{array}{l}\text { fresh } \\
\text { state }\end{array}$ & $\begin{array}{l}\text { at curing ages of } \\
7 \text { and } 28 \text { days }\end{array}$ & $\begin{array}{l}\text { at curing } \\
\text { age of } 28 \\
\text { days }\end{array}$ \\
\hline
\end{tabular}

The maximum dry density and optimum water content of all mixture designations are obtained for the fresh state of the mixture in accordance with the ASTM D558 (ASTM 1996). According to the standard procedure, the aggregates of native soil are separated into two coarse and fine fractions based on the passing and retaining on the sieve No. 4. The coarse fraction of native soil is saturated, but the surface of aggregates is dried to achieve the saturated surface dried (SSD) state. The fine fraction of native soil is dried. Then the predetermined amount of dried fine additive (kaolinite or bentonite) is supplied to attain the specific weight ratio of fine additive in native soil. The whole of fine additive is added to the fine fraction of native soil. In the next stage, the predetermined weight of cement is added to the combination of the fine fraction of native soil and fine additive. The dry mixture is carefully blended to make a high degree of uniformity. In the next step, the water is added to dry admixture and then a coarse fraction of the native soil in SSD state is added to the wet admixture to prepare the final state of the mixture. Then, the dry density of the fresh mixture is measured at various moisture content and the optimum water content and maximum dry density are determined from the compaction curve.

The test specimens of the uniaxial compressive strength test are prepared with the aforementioned procedure and the fresh mixture with optimum water content is compacted in a cylindrical mold with a height of 11.64 $\mathrm{cm}$ and a diameter of $10.16 \mathrm{~cm}$ to achieve the maximum dry density (i.e. relative compaction of $100 \%$ ). After the samples are cured in the moisture room after the age of 28 days, the uniaxial compression strength is measured for all mixture designations in accordance with the ASTM D1633 standard (ASTM 2007a). The 
loading jack in the uniaxial compressive strength test apparatus is controlled by a stress rate of $120 \mathrm{kPa} / \mathrm{s}$ which falls within the acceptable range of ASTM standard.

The permeability of cemented mixtures is measured in a flexible wall permeameter chamber in accordance with the ASTM D5084 standard (ASTM 1990). A cylindrical compacted specimen with a diameter of $10 \mathrm{~cm}$ and height of $20 \mathrm{~cm}$ is prepared for each cemented mixture. The fresh mixture is prepared with the same procedure with compaction test. Then, the fresh mixture with optimum water content is poured into the mold in three layers and compacted to achieve maximum dry density. The mixtures comprised of $S$ soil are cured for two ages of 14 and 27 days by submerging in a water pool and the permeability of samples is measured at these curing ages. For mixtures comprised of $\mathrm{G}$ soil, the permeability is measured after curing age of 28days by submerging in a pool. In the permeability test, the hardened mixture is covered by a thin latex membrane and is installed inside a large scale cell. Then the test specimen is saturated by circulating distilled water from the sample bottom cap to the upper cap. To achieve full saturation in the sample, a back pressure of $200 \mathrm{kPa}$ is kept in the test sample until the test termination. By this method, the target B-value of $95 \%$ is adjusted in the sample. In the next step, water under a constant head of $244 \mathrm{~mm}$ flowed from the sample bottom and discharge throughout the sample upper cap is measured. Therefore, the permeability of the mixture is measured with the constant head method.

In addition to the cemented mixtures, some treated mixtures are prepared by mixing the native soils of S or $\mathrm{G}$ with various contents of kaolinite additives and no cement agent is added. The weight percent of kaolinite additive in treated mixtures is selected about $0,10,20$ and $30 \%$ which is similar to the cemented mixtures. The compaction tests are conducted for all treated samples in accordance with the ASTM D698 (ASTM 2012). Then, the permeability test of treated mixtures is conducted in a rigid wall permeameter chamber in accordance with the ASTM D5856 (ASTM 2007b). The specimens of permeability tests have a diameter of 10 $\mathrm{cm}$ and a height of $10.3 \mathrm{~cm}$.

\section{4- Compaction Test Results}

The compaction parameters of all mixtures are determined before permeability tests. Regrading to a large number of compaction tests, only the compaction curve (i.e. the graph of dry density versus water content) of cemented sand and cemented gravel mixtures with a low cement content of $5 \%$ is presented in Figs. 2 and 3 , respectively. However, compaction parameters involving the maximum dry density and optimum water content are presented for all mixtures in Figs. 4 to 8. The graphs of maximum dry density and optimum water content versus cement content for the cemented mixtures with no fine additive are shown in Fig. 4 . The cement agent slightly influences the maximum dry density and optimum water content and by increasing the cement content in mixtures without any fine additive, the maximum dry density increases, and in turn optimum water content decreases. As the cement powder tends to absorb water and forms a gel in the fresh mixture, the cement gel covers around the soil grains and facilitates the grains to be well packed, and thus the optimum water content decreases. Furthermore, as seen in both Fig. 2-a and 3-a, the compaction curve of mixtures are separately different in all ranges of water content and, the mixture with higher cement content gets more density at a specific water content. Thus, the cement agent facilitates well densification of the fresh mixture in

all range of water contents. By comparing the compaction parameters of mixtures with different native soils, it can be seen that the sandy soil has a proper response with cement agent and the cemented sand mixtures 
have greater maximum dry density and optimum water content in comparison with the gravel mixtures in the same cement content. In fact, the sandy mixture has a greater specific surface and, thus needs more water to attain the optimum compaction condition. This consequence was previously observed for compaction of cement treated soils (Mohamedzein and Al-Rawas 2011; Reddy and Kumar 2011; Wu et al. 2011).

When the bentonite powder is added to the cemented mixtures, the compaction specifications of mixtures are considerably influenced. The graphs of maximum dry density and optimum water content for groups of cemented sand and cemented gravel mixtures having identical cement content are presented in Figs. 5 and 7 , respectively. In a group of mixtures with the same cement, maximum dry density is regularly decreased and in turn, the optimum water content is significantly increased by increasing the bentonite content in the mixture. The most impact of bentonite is observed in the optimum water content in such a way that by increasing the bentonite content from 0 to $30 \%$, the optimum water content increases in a range between 60 to $70 \%$ in both sand and gravel mixtures. The high tendency of bentonite particles for water absorption causes that a great portion of water in the fresh mixture is spent for bentonite particles and the fresh mixture requires more moisture to attain the optimum condition in the compaction test. Besides, the bentonite particles are swelled after absorbing the moisture. Therefore, the swelled bentonite particles with less weight are placed in a space with more volume in fresh mixture and reduce the maximum dry density of the mixture. By comparing the compaction curve of cemented sand mixtures with different bentonite contents in Figs. 2-b, it can be seen that even though the dry part of the compaction curve of mixtures is separately distinguished, however the wet part of the compaction curve is superimposed and the dry density of mixtures compacted with moisture greater than optimum water content falls is close range. Besides, the density of fresh mixture compacted with higher moisture is considerably reduced and becomes less than the maximum dry density state. This fact is due that at high water contents, the density of the mixture is principally governed by swelled bentonite particles and the swelled particles of the bentonite cause a negative influence on the density of mixture. In other hand, at lower water content, the bentonite particles absorb less water and behave as near dry grains. Thus, the semi dry particles of bentonite only fill the void spaces that existed in the fresh mixture. The different role of bentonite in dry and wet parts of compaction curves is observed in cemented gravel mixtures containing bentonite additive which is shown in Fig. 3-b.

The compaction curve of cemented sand and cemented gravel mixtures with $5 \%$ cement and enriched with the kaolinite additive is presented in Figs. 2-c and 3-c, respectively. Furthermore, the graphs of the maximum dry density and optimum water content for these mixtures are sketched in Fig. 6 and Fig. 8. In contrast to the mixtures with bentonite additive, the compaction curve of mixtures with various amounts of kaolinite additive falls in close range. Besides, the kaolinite content has less influence on the maximum dry density and optimum water content of mixtures. In a group of cemented sand mixtures with identical cement content, the greatest optimum water content occurs in the mixture with $20 \%$ kaolinite. In cemented gravel mixtures with equal cement content, the optimum water content increases with increasing the kaolinite additive and the greatest optimum water content occurs in mixtures with $30 \%$ kaolinite. However, the difference of optimum water content between the mixtures with the same cement and various kaolinite is limited up to $25 \%$. In fact, the kaolinite particles have less tendency to absorb water in fresh mixtures and, thus do not considerably affects the optimum water content of mixtures. 
The maximum dry density of mixtures with kaolinite additive is related to the interaction of kaolinite particles with the void space of native soil and cement content. In mixtures with less cement content of $5 \%$, the greatest value of maximum dry density occurs in a mixture with a kaolinite content of $10 \%$. In other words, the kaolinite considerably fills the void spaces between coarse grains in this mixture and causes to emerge the best packing of grains inside the mixtures. By increasing the kaolinite percent in the mixture, the kaolinite particles with less weight occupy more volume in the mixture and the maximum dry density of the mixture reduces. In the group of mixtures with a higher cement content of $15 \%$, the mixture without kaolinite has the greatest dry density and by adding kaolinite to the mixtures, the maximum dry density is reduced.

From the compaction test results, it can be said that the compaction of mixtures is primarily governed by the type and content of the fine-grained additive in the mixture rather than the cement content. Furthermore, even though increasing the cement in the mixture with no fine additive reduces the optimum water content, this trend is turned in mixtures with fine additive and the greatest optimum water content among mixtures with the same fine additive is found in the mixture with higher cement.

\section{5- Compressive Strength Of Mixtures}

One key factor of cement stabilized soils is the uniaxial compressive strength. The cemented sand-gravel (CSG) mixture used in the main body of the hardfill dams should have adequate strength and stiffness to withstand the reservoir and gravity and other seismic loads (Jia et al. 2016). As the water tightening element of the hardfill dam is placed on the upstream face of the dam with a steep slope and subjected to the hydrostatic pressure of the reservoir, the impervious material used in the water tightening part of the dam should have sufficient strength. Thus, the uniaxial compressive strength of cemented mixtures with various fine additive is investigated.

The graph of uniaxial compressive strength versus cement content for cemented mixtures without fine additive and cured at two ages is shown in Fig. 9. As expected, the cement agent improves the strength of mixtures, and by increasing the cement content from 5 to $15 \%$, the uniaxial strength of cemented sand and cemented gravel mixture at curing age of 28 -day is increased about $322 \%$ and $196 \%$, respectively. Thus, the most influence of cement is found in stabilized sand rather than the stabilized gravel. However, the cemented gravel mixture has higher strength in all cement contents in comparison with the cemented sand. The influence of curing age on enhancing the strength of mixtures is related to the base soil type and cement content in the mixture. By ending the curing process and completing the cement hydration, more strength is achieved in sand mixtures, and in contrast, curing age has less influence on the cemented gravel mixture. For instance, the difference of compressive strength in cemented sand and cemented gravel mixtures with $15 \%$ cement between two curing ages of 7 and 28 days is about 110.8 and $21 \%$, respectively. The native soil of $G$ originally has larger grains in comparison with the $S$ soil. Thus, the higher number of contact existed between grains of the $S$ soil and the great number of bonding between grains is established due to cementation in cemented sand mixtures. By completing the hydration process of cement gel, the bonding between grains are gradually developed and causes to enhance the compressive strength of the mixture. The other important consequence is that the improvement rate of strength after the curing process increases with an increase in the cement content of the mixture. 
When the fine additive is added to the cemented sand and cemented gravel mixtures, the trend of compressive strength in mixtures completely changes. The intensity and performance of fine-grained additive on the strength of cemented mixtures are related to the interaction between three parameters of cement content, additive type and content in the mixture. In the cemented sand mixture with a low cement content of $5 \%$ (Fig. 10), the compressive strength of the mixture is improved by adding any percentage of fine-grained additive in any type. The most increasing of compressive strength is found in mixtures with $10 \%$ of the fine additive. Besides, the kaolinite additive has greater performance in enhancing the strength of cemented sand mixture with $5 \%$ cement in comparison with the bentonite additive. The aforementioned trend about the positive role of fine additive on the strength of low cement mixture is observed in both curing ages. In fact, regarding the low percentage of cement in sand-cement mixture, the cemented sand mixture initially has low strength. When the bentonite or kaolinite additive is added to the mixture, the fine particles of additive fill the void spaces between coarse grains of native soil in the mixture and help to establish a well-packed texture in the base soil of the mixture. The best packing of grains in base soil is developed in the mixture with $10 \%$ fine additive where this mixture gets maximum strength and highest dry density among the mixture with the same cement content. Furthermore, the difference of compressive strength of mixtures with low cement content between two curing ages of 7 and 28 days lies in close range. For instance, the increasing rate of compressive strength in mixtures with $5 \%$ cement and various bentonite content after curing age of 28 days varied between 50 to $70 \%$. Thus, it can be seen that bentonite additive has a less negative influence on the hydration process of cement binder in low cement mixture and in turn, improve the base soil matrix in the cemented mixture and enhances the strength.

When the cemented sand mixture is prepared with the highest cement content of $15 \%$, the role of fine additive in the mixture is changed and the performance of fine additive on the strength of mixture depends on the type and amount of additive. In mixtures containing the bentonite additive, adding any content of bentonite significantly reduces the compressive strength of mixtures. In fact, the cemented sand mixture with no additive has originally higher compressive strength. The bentonite additive has a high tendency to absorb moisture existed in the fresh mixture and disrupt the hydration process of cement. This issue can be recognized by considering the evolution rate of compressive strength between two curing ages of 7 and 28 days. Even though the compressive strength of the mixture with $15 \%$ cement and no bentonite additive is increased about $110 \%$ after curing age of 28 days, this rate is regularly decreased for other mixtures with the same cement and bentonite additive.

The performance of kaolinite additive in high cement mixtures considerably differs from bentonite additive. Adding $10 \%$ of kaolinite additive to the cemented sand mixture increases the compressive strength by imposing a strong matrix and the best packing in base soil. Further increasing the kaolinite additive by more than $20 \%$ reduces the compressive strength. In the mixtures with higher kaolinite content of $30 \%$, the specific surface of base soil in the mixture considerably increases in comparison with the mixture with no kaolinite additive. Thus the cement agent is not sufficient to cover all grains of base soil in the mixture with $30 \%$ kaolinite and the cementation effect reduces. It should be noted that the evolution rate of compressive strength in mixtures with various kaolinite contents and $15 \%$ cement after curing age of 28 days are close and varies between $93 \%$ and $110 \%$. Therefore, the kaolinite additive has a less negative and disruptive role on the hydration process of cement agent in cemented mixture. 
The impact of fine-grained additive on the strength of cemented gravel mixture depends on the additive type. As shown in Fig. 11-a, adding bentonite powder to the cemented gravel mixture in all cement contents has a negative influence on the strength of the mixture and by increasing the bentonite in the mixture with identical cement content, the compressive strength of mixtures is decreased. The intensity of decreasing in compressive strength is associated with cement content of mixture and the largest reduction of compressive strength due to adding bentonite occurs in mixture with the highest cement content. For instance, by increasing the bentonite content from 0 to $10 \%$ in mixtures with the cement contents of 5,10 and $15 \%$, the compressive strength falls about 20,44 and $55 \%$, respectively. The bentonite additive influence not only the magnitude of compressive strength of the mixture but also the evolutionary rate of compressive strength after the curing process. By increasing the bentonite additive in the mixture with identical cement content, the increasing rate of compressive strength between two curing ages of 7 and 28 days decreases. In mixtures with $15 \%$ cement, the increasing rate of compressive strength after 28 -day curing decreases from $21 \%$ for mixture with no bentonite to $9 \%$ for mixture with $30 \%$ bentonite.

The performance of the kaolinite additive in cemented gravel mixture differs from the bentonite additive. As seen in Fig. 11-b, adding 10\% kaolinite to the pure cemented gravel mixture leads to an increase in the compressive strength and this increase is observed in all cement content. Then by further increasing the kaolinite additive in the mixture, the compressive strength decreases. The maximum increase of strength due to adding $10 \%$ kaolinite occurs in a low cement mixture which is about $21 \%$. As expressed earlier for compaction of cemented gravel mixtures with 5 and $10 \%$ cement contents, the mixture with $10 \%$ kaolinite has comparatively high maximum dry density among other mixtures with the same cement content. Thus the grains of base soil in the mixture with $10 \%$ kaolinite are well packed under compaction effort and base soil in the mixture get a strong matrix and texture in comparison with the cemented mixture with no kaolinite additive. Thus, the compressive strength of the mixture with $10 \%$ kaolinite becomes greater than the mixture with no kaolinite additive. Furthermore, according to the previous investigations of Tabet et al. (2018), the kaolinite mineral participates in the hydration process of cement in stabilized soil and the kaolinite turns to the cement gel products. Chrysochoou (2014) observed dissolution of the kaolinite mineral in stabilized soil with cement. The released kaolinite particles corporate in cement hydration which leads to an increase in calcium silicate hydration ( $\mathrm{CSH}$ ) compounds and improves the strength of stabilized soil. Thus, the kaolinite additive can help to cementation process of the cement agent.

\section{6- Permeability Of Cemented Sand Mixtures}

The results of the permeability test for cemented sand mixtures enriched with kaolinite additive and cured at both ages of 14 and 28 days are shown in Fig. 12-b. Besides the permeability of the sand-kaolinite mixture with no cement agent is measured via a rigid-wall permeameter chamber and the permeability graph of these mixtures versus various kaolinite contents is shown in this figure. According to the test results, the permeability of mixtures involving the same cement content regularly decreases by adding kaolinite additive. Furthermore, the permeability of cemented mixtures with identical kaolinite content is reduced by increasing the cement content.

The influence of kaolinite additive on the permeability of the cemented sand mixture depends on the cement content in the mixture. In sand-kaolinite mixture groups which are comprised of sand and kaolinite with no 
cement agent, the permeability reduces from $9.48 \times 10^{-4} \mathrm{~cm} / \mathrm{s}$ to $3.01 \times 10^{-4} \mathrm{~cm} / \mathrm{s}$ by increasing the kaolinite content from 0 to $30 \%$ which means that the permeability ratio becomes about 0.32 . However, when the mentioned amount of kaolinite is added to the cemented mixture, further reduction in permeability is observed. For instance, in a mixture group containing 5\% cement and cured at the age of 28 days, the permeability reduces from $2.34 \times 10^{-4} \mathrm{~cm} / \mathrm{s}$ to $3.06 \times 10^{-5} \mathrm{~cm} / \mathrm{s}$ by increasing the kaolinite content from 0 to $30 \%$ where the permeability ratio becomes about 0.1 . Furthermore, by same increasing the kaolinite additive in the mixture groups with cement of $10 \%$ and $15 \%$, the permeability ratio is obtained as 0.18 and 0.17 , respectively.

By comparing the permeability of mixtures with identical kaolinite content and different cement at the curing age of 28 days, it can be seen that the permeability of the mixture considerably decreases with adding the cement agent. However, the intensity of cement impact is related to the kaolinite content in the soil. In pure sand with no kaolinite additive, by increasing the cement content from $0-15 \%$, the permeability reduces from $9.48 \times 10^{-4} \mathrm{~cm} / \mathrm{s}$ to $3.91 \times 10^{-5} \mathrm{~cm} / \mathrm{s}$ which the permeability ratio is about 0.041 . However, in three cemented mixture groups which the base soil comprised of sand with $10 \%$ kaolinite, sand with $20 \%$ kaolinite and sand with $30 \%$ kaolinite, the same increase in cement content from 0 to $15 \%$ results a permeability ratio of 0.023 , 0.022 and 0.015 , respectively. This implies that if the base soil in cemented mixture has a sufficient amount of fine additive for filling the void spaces, the cement agent performs in proper condition with base soil and has more efficiency on the reduction of permeability of mixture.

The permeability of cemented mixtures depends not only on the kaolinite and cement content but also on the curing condition of mixtures. By comparing the permeability of a specific cemented mixture at two curing ages of 14 and 28 days, the permeability is reduced after completing the hydration process of cement paste in the mixture. In mixtures with cement of $5 \%$, the permeability reduction occurs with less intensity and the permeability ratio in a mixture between two curing ages of 7 and 28 days is varied in a range between 0.46 and 0.89 . When the cement content increases in mixtures, the hydration of cement occurs with high intensity and the completion of cement curing helps to reduce the permeability. In mixture groups with $15 \%$ cement, the permeability ratio of mixtures between two curing ages varies in a range between 0.25 and 0.41 . It is interesting to know that the maximum decreasing of permeability after curing occurs in the mixture with $10 \%$ kaolinite among the mixtures containing the same cement content.

The descending trend of permeability with kaolinite content in cemented sand-kaolinite mixtures is contradicting with the strength properties of mixtures. As previously thought, the strength of mixtures with identical cement content increases with adding the kaolinite content up to $10 \%$ and then decreased for a further percentage of the kaolinite. In fact, the kaolinite impacts on the strength of mixture in such a way that kaolinite powder interacts with the bonding role of cement and acts on the structure of the mixture. In contrast, the permeability of the cement mixtures is regularly decreased by adding the kaolinite additive. The reason is that the kaolinite particles fill the void spaces of cemented mixture and cause to block the seepage path inside the mixture. Furthermore, the cement gel in the fresh mixture leaks into the remained void spaces existing between fine grains of kaolinite powders and helps to fulfill the seepage paths in the mixture. By completing the curing process and hardening the cement paste, further blockage of mixture porosity space is attained. Therefore, the permeability of mixture is governed by the cement and kaolinite role in relation with the filling 
the porosity and the bonding between grains due to cementation has less influence on the permeability of mixture.

The permeability graph of cemented sand mixtures enriched with bentonite additive is shown in Fig. 12-a. The permeability graph of mixtures with different bentonite additives follows the same descending trend observed for the mixtures enriched with kaolinite and permeability of cemented sand mixtures regularly decreases with adding further bentonite additive. However, the intensity of bentonite influence on the reduction of mixture permeability differs from the kaolinite.

When the mixtures have low cement of $5 \%$, the kaolinite has more influence on the permeability reduction of mixtures rather than the bentonite additive. By increasing the bentonite content from 0 to $30 \%$ in the mixtures group with $5 \%$ cement, the permeability of mixtures at the age of 28 days decreases from $2.34 \times 10^{-4} \mathrm{~cm} / \mathrm{s}$ to $1.28 \times 10^{-4} \mathrm{~cm} / \mathrm{s}$ where the permeability ratio becomes about 0.549 . The bentonite additive has a characteristic role in the permeability reduction of mixtures that involve higher cement content. In the mixture group with a cement content of $15 \%$ and cured for 28 days, by increasing bentonite content from $0-30 \%$, the permeability reduces from $3.01 \times 10^{-5} \mathrm{~cm} / \mathrm{s}$ to $3.32 \times 10^{-6} \mathrm{~cm} / \mathrm{s}$ with the permeability ratio of 0.115 . This implies that in order to attain the complete efficiency of bentonite in permeability reduction of the cemented sand mixture, a sufficient amount of cement should be presented in the mixture.

The cement role in the permeability of mixtures is completely associated with the bentonite content presented in the base soil. In the mixtures which base soil comprised of sand with an identical bentonite content of $10 \%$, by increasing the cement content in the mixture from $5 \%$ to the $15 \%$, the permeability reduces from $1.23 \times 10^{-4}$ $\mathrm{cm} / \mathrm{s}$ to $1.17 \times 10^{-5} \mathrm{~cm} / \mathrm{s}$ with the permeability ratio of 0.09 . In mixtures comprised of similar base soil with $10 \%$ kaolinite, the permeability ratio for the same increase in cement content from $5-15 \%$ becomes 0.12 . However, when the base soil in the mixture has extreme bentonite content of $30 \%$, the permeability of mixtures falls from $1.28 \times 10^{-4} \mathrm{~cm} / \mathrm{s}$ to $3.32 \times 10^{-6} \mathrm{~cm} / \mathrm{s}$ for cement content increasing from 5 to $15 \%$ and permeability ratio becomes 0.03 . Thus, in order to attain the maximum performance of cement agent in permeability reduction of cemented soil mixture, the base soil should have a sufficient amount of bentonite powders. This consequent about the positive role of bentonite on the permeability is contradicting with the negative role of bentonite in the compressive strength where the bentonite reduces the strength of the cemented mixture.

Another parameter affecting the permeability of mixtures with bentonite additive is the curing age. Like the mixture having kaolinite additive, the intensity of the impact of curing age is related to the cement content in the mixture. In mixture groups with low cement of $5 \%$, the curing age has less effect on the permeability and, the permeability of mixtures at two curing ages of 14 and 28-days is close with an except of the mixture with no bentonite. This result implies that the hydration process of cement agent and hardening of the mixture has less impact on the permeability and the swelling of bentonite agent plays the major role in the permeability functioning of the mixture with low cement. By increasing the cement participant in the mixtures, more reduction in permeability occurs after completing the hydration process of cement. In the mixture group with $15 \%$ cement, the permeability of the mixture with $10 \%$ bentonite reduces from $5.91 \times 10^{-5} \mathrm{~cm} / \mathrm{s}$ to $1.17 \times 10^{-6}$ $\mathrm{cm} / \mathrm{s}$ after completing the curing process where the permeability ratio between two curing ages is about 0.198 . This ratio for mixture with $15 \%$ cement and $30 \%$ bentonite becomes 0.543 . It should be noted that 
among the mixtures with the same cement content and identical additive type, the greatest change in permeability between two curing ages is observed in the mixture with $10 \%$ additive.

\section{7- Permeability Of Cemented Gravel Mixture}

Regarding to low rise of compressive strength of cemented gravel mixtures after curing completion of samples, the permeability of cemented gravel mixtures is measured at the age of 28 days. The graph of permeability of cemented gravel mixtures versus kaolinite content is presented in Fig. 13-b. Furthermore, the permeability of gravel-kaolinite mixtures with no cement binder is shown in this figure. Like the cemented sand-kaolinite mixtures, the kaolinite additive considerably reduces the permeability of cemented mixture. However, the intensity and variation of permeability with kaolinite content in cemented gravel mixture differ with the cemented sand mixtures. By adding $10 \%$ of kaolinite additive to the cemented gravel mixture (with no additive) in all cement contents, the permeability of gravel mixture considerably drops in such a way that the permeability ratio between cemented gravel mixture with no kaolinite and cemented mixture with $10 \%$ kaolinite varies between 0.05 to 0.16 . This ratio for cemented sand mixture with $10 \%$ kaolinite becomes about 0.3 to 0.5 . However, by adding further kaolinite greater than $10 \%$ to the cemented gravel mixture, the permeability of the mixture does not considerably vary and becomes almost constant. This trend is in contrast with the descending trend observed for the cemented sand mixture where permeability regularly reduces with increasing kaolinite content in the mixture. It should be noted that the proper performance of kaolinite additive in reducing the permeability of gravel soil mainly occurs in cemented stabilized gravel rather than the pure gravel. By adding $30 \%$ of kaolinite to the pure gravel soil, the permeability reduces from $1.95 \times 10^{-3} \mathrm{~cm} / \mathrm{s}$ to $2.89 \times 10^{-4} \mathrm{~cm} / \mathrm{s}$ which the permeability ratio is about 0.15 . However, if this amount of kaolinite is added to the cemented gravel mixture with $5 \%$ cement, the permeability falls from $6.84 \times 10^{-4} \mathrm{~cm} / \mathrm{s}$ to $1.45 \times 10^{-5} \mathrm{~cm} / \mathrm{s}$ with the permeability ratio of 0.02 .

The performance of cement agent and its effect on the permeability of cemented gravel-kaolinite mixtures is associated with kaolinite content in the mixture. If the gravel soil is only blended with cement without any kaolinite additive, the permeability of mixture frequently is reduced with increasing the cement content. However, the kaolinite additive changes the trend of the mixture permeability with cement. If the permeability of cemented mixtures with identical kaolinite is compared, the permeability of all cemented mixtures with various cement content is considerably lower than the gravel-kaolinite mixture with no cement. However, the permeability of all cemented mixtures with identical kaolinite content lies in close range, and increasing cement content has less influence on the permeability of mixtures. This consequent is more distinctive in the mixtures with $30 \%$ kaolinite.

The permeability of cemented gravel mixtures enriched with bentonite additive is presented in Fig. 13-a. The trend of permeability variation with the bentonite additive in the cemented gravel mixture is analogous with the cemented sand mixtures which is shown in Fig. 12-a. The bentonite additive efficiently improves the impervious specification of cemented gravel mixtures and the permeability of cemented mixtures is gradually decreased by adding further bentonite. The permeability ratio between two mixtures involving 0 and $30 \%$ bentonite and containing the same cement content of $5 \%$ becomes about 0.29 . This ratio for the same increase of bentonite in cemented sand mixture with $5 \%$ cement is about 0.55 . This fact implies that as the 
cemented gravel mixture has originally higher permeability rather than the cemented sand mixture, the permeability of gravel-cement mixture is mostly influenced by adding bentonite powder. When the cement content increases in gravely mixtures, adding bentonite additive to the mixtures outcomes more distinctive decreasing in permeability. In mixtures with cement content of $15 \%$, by increasing the bentonite content from 0 to $30 \%$, the permeability reduces from $1.06 \times 10^{-4} \mathrm{~cm} / \mathrm{s}$ to $2.75 \times 10^{-6} \mathrm{~cm} / \mathrm{s}$ revealing a permeability ratio of 0.03 .

In contrast to the cemented gravel mixtures containing kaolinite additive, increasing the cement agent content helps to reduce the permeability of cemented gravel-bentonite mixtures and by increasing the cement content in mixtures with identical bentonite additive, the permeability gradually reduces. The most decreasing of permeability with cement content is observed in mixtures with higher bentonite content and by increasing the cement content from 5 to $15 \%$ in mixtures with $30 \%$ bentonite, the permeability ratio becomes about 0.03 .

Regarding to the permeability tests of cemented gravel mixtures, the bentonite additive has a characteristic influence on the reduction of mixture permeability. The greatest performance of bentonite additive is achieved by presenting an adequate amount of cement agent in the mixture. In other hand, the performance of kaolinite additive in the reduction of permeability of cemented gravel mixture is limited, and adding more kaolinite additive has no impact on the permeability. In fact, as there are many open voids in the gravel mixture, the bentonite powders are swelled and elaborately fill the void spaces in the mixture. The remained void spaces are filled by cement gel and, thus, increasing the cement agent helps to reduce the permeability in the cemented mixture containing bentonite additive. In contrast, the kaolinite particles have constant volume and the particles fill the open void space of the mixture to a certain extent and some open void remains in the mixture. Thus, the cement agent is not capable to carry out fulfilling the remaining void spaces and thus, the performance of cement in mixtures with kaolinite additive is limited.

\section{8- Effect Of Binder Type On The Permeability Of Cemented Mixture}

In order to investigate the separate effect of cement and kaolinite additives on the permeability of treated soil, the permeability of pure sand and treated sand having the same content of additives is compared. The permeability of pure sand without any cement agent or kaolinite additive is measured about $9.48 \times 10^{-4} \mathrm{~cm} / \mathrm{s}$. In other hand, two mixtures which are comprised of pure sand and equal $10 \%$ content (by weight) of cement or kaolinite are selected and denoted by S-C10 and S-C0-K10 symbols, respectively. These three samples are marked by red circles in the permeability graph of Fig. 12-b. The permeability of S-C10 and S-C0-K10 mixtures is measured about $5.1 \times 10^{-4} \mathrm{~cm} / \mathrm{s}$ and $7.1 \times 10^{-5} \mathrm{~cm} / \mathrm{s}$, respectively. Thus, the permeability ratio between treated sand of S-C10 and pure sand becomes about 0.074. Besides, the permeability ratio between S-C0-K10 and pure sand is about 0.54 . Comparing the permeability ratio for these two mixtures implies that the cement agent has more influence on reducing the permeability of pure sandy soils rather than the kaolinite additive when the additive is separately added to the pure sand. This consequent is observed in the treated gravel soil. The permeability of three samples of pure gravel, gravel-cement mixture with $10 \%$ cement and gravel-kaolinite mixture with $10 \%$ kaolinite additive (marked by red circles in the graph of Fig. 13-b) is compared. The permeability ratio between kaolinite treated gravel and pure gravel is obtained as 0.54 . However, the 
permeability ratio between cement treated gravel and pure gravel becomes 0.21 . Thus, the cement has more influence on the permeability of treated gravel rather than the kaolinite.

\section{9- Sem Analysis Of Cemented Sand Mixtures}

To explore the aforementioned consequences, the microstructure of sand-cement mixtures with $5 \%$ cement and containing both fine additives is investigated. The SEM images of these mixtures under 500x magnification are shown in Fig. 14.

In the mixture of S-C5 (Fig. 14-a), the cement paste covers the coarse grains of sand soil and slightly fills the void spaces between grains. The cement paste exhibits as the needle-shape bonds which are referred as the ettringite and calcium hydroxide crystals. These crystals are emerged by the cement hydration in concrete and soil-cement mixtures (Moon et al. 2009; Choobbasti and Kutanaei 2017; Preetham and Nayak 2019) and cause bonding between grains.

The kaolinite powders are apparently observed between coarse grains of sand soil in the mixture of S-C5-K10 (Fig. 14-c) and slightly fill the void space of the specimen. Furthermore, the needle-shaped crystals of cement paste are found around the grains of both kaolinite powders and sand grains and make an adhesion between sand and kaolinite grains. Besides, some needle crystals of cement paste emerge throughout kaolinite powders which implies that kaolinite powders are participants in the hydration process of cement. This issue leads to develop some strong bonding in the mixture with $10 \%$ of kaolinite additive.

In the S-C5-B10 mixture (Fig. 14-b), the bentonite minerals are exhibited in the form of swelled platy shapes which are extended into the void space of sand aggregates. However, the intensity of needle-shaped crystals of cement paste is decreased and bentonite causes to reduce the impact of the cement hydration in the mixture. As the bentonite influences the cement hydration in the mixture, the evolution rate of uniaxial strength of mixture after curing is decreased which be discussed earlier.

As shown in Figs. 14-d, the majority of interior space in the S-C5-B30 mixture is occupied by the bentonite swelled platy particles, and the void space in the mixture is efficiently filled by these platy particles. Thus, the higher percentage of swelled bentonite powders efficiently fulfill the void space, and the permeability of the mixture considerably drops. However, as the intensity of needle-shape of cement paste decreases in the SEM image, the hydration of cement in the mixture is disrupted which leads to reduce the strength of the mixture.

The SEM image of the S-C5-K30 mixture is shown in Fig. 14-e. The kaolinite particles dominate the majority of mixture matrix and kaolinite particles cover the grains of native soil. Regarding to the low tendency of kaolinite to swell, the kaolinite particles in the mixture are found as the spherical particles without swelling which are not capable to seal all void spaces in the mixture. Therefore, the kaolinite powder has comparatively low performance in reducing the water flow path in comparison with the swelled bentonite additive.

\section{0- Conclusion}

In the current research, the compaction, uniaxial compression strength, permeability and SEM images of cemented sand and cemented gravel mixtures containing fine-grained additives are investigated in order to 
attain a low permeable with sufficient strength kind of CSG mixture. The following consequences are obtained from the test results:

- The compaction parameters of the cemented mixtures are associated with the cement content and the cement agent facilitates well densification of the fresh mixture in all moisture ranges. By increasing the cement content in mixtures, the maximum dry density increases, and in turn the optimum water content decreases.

- The bentonite particles in the cemented mixture are swelled and considerably influence the compaction of the mixture. Increasing the bentonite additive in cemented mixtures leads to regularly decreasing in maximum dry density and considerably increasing in the optimum water content of the mixture. Besides, the density of the mixture compacted with high moisture is totally governed by swelled bentonite particles.

- The compaction of cemented mixtures with various amounts of kaolinite additive falls in close range. Besides, the kaolinite content has less influence on the maximum dry density and optimum water content of mixtures. In low cement mixtures, the greatest value of maximum dry density occurs in the mixture with a kaolinite content of $10 \%$. In high cement mixtures, the maximum dry density of cemented mixture with no fine additive is greater than the mixtures containing kaolinite additive.

- The strength of cemented mixtures is related to the interaction between the three parameters of cement content, additive type, additive content in the mixture.

- When cemented sand and cemented gravel mixtures contain kaolinite additive, the mixture enriched with $10 \%$ of the kaolinite additive has the greatest compressive strength among the mixtures involving similar cement and fine additive type. The kaolinite powders with a content of $10 \%$ impose the best packing of grains and strong texture in the base soil.

- The performance of bentonite additive on the strength of cemented mixtures depends on the native soil type and cement content. The bentonite additive in cemented sand mixtures with low cement improves the strength. In other hand, adding bentonite powders to the cemented sand mixture with high cement content reduces the strength.

- As the cemented gravel mixture with no fine additive has initially high strength, presenting any bentonite in the base soil of the mixture has a disrupted effect on the cement hydration and the compressive strength reduces with increasing the bentonite content in the mixture. The negative role of bentonite additive on the strength of the mixture is comparatively found in mixtures with high cement content.

- The growth of mixture strength after curing completion varies in cemented gravel and cemented sand mixtures. The cemented gravel mixture initially owns higher strength the growth of compressive strength after curing is low. In contrast, the complete state of compressive strength for the cemented sand mixtures is attained after completing the hydration age.

- The permeability of mixtures is related to the amount of cement and fine additive in the cemented sand mixture and by increasing the fine additive regardless of additive type, the permeability is regularly decreased. The most decreasing in permeability is attained in mixtures enriched by bentonite and involving higher cement content.

- The kaolinite additive has limited influence on lowering the permeability of the cemented gravel mixture. In other hand, the permeability of cemented gravel mixtures considerably decreases with increasing the 
bentonite content in mixture.

- In order to attain the maximum performance of fine-grained additive in the reduction of permeability of cemented mixtures, the cement agent with higher content should be used in the mixture. In this research, the lowest permeability of cemented mixtures is achieved in cement content of $15 \%$.

- It can be concluded that if one seeks an impervious type of cemented mixture, it is recommended to implement a higher amount of bentonite (with the weight ratio of $30 \%$ ) in presence of adequate cement content in mixing. In contrast, if the higher strength is intended, the fine additive content in the mixture should be set to $10 \%$. The maximum efficiency for the strength of mixture is attended by adding kaolinite additive with an amount of $10 \%$.

\section{References}

1. Álvarez L (1982) Characteristic of the plastic concrete of the diaphragm wall of Converto Viejo Dam. XIV ICOLD:371-390

2. ASTM (1990) ASTM D5084 Standard test method for measurement of hydraulic conductivity of saturated porous materials using a flexible wall permeameter. American Society for Testing and Materials. Annual Handbook, vol 4. West Conshohocken, PA

3. ASTM (1996) ASTM D558, Standard test methods for moisture-density relations of soil-cement mixtures. American Society for Testing and Materials. Annual Handbook, vol 5. West Conshohocken, PA

4. ASTM (2007a) ASTM D1633 Standard Test Methods for Compressive Strength of Molded Soil-Cement Cylinders, ASTM International, West Conshohocken, PA, USA. American Society for Testing and Materials. Annual Handbook. West Conshohocken, PA

5. ASTM (2007b) ASTM D5856 Standard Test Method for Measurement of Hydraulic Conductivity of Porous Material Using a Rigid-Wall, Compaction-Mold Permeameter. American Society for Testing and Materials. Annual Handbook. ASTM International, West Conshohocken

6. ASTM (2012) ASTM D698, Standard test methods for laboratory compaction characteristics of soil using standard effort. In: Annual Book of ASTM Standards. American Society for Testing and Materials. Annual Handbook. ASTM Philadelphia (PA)

7. Batmaz S (2003) Cindere dam-107 m high roller compacted hardfill dam (RCHD) in Turkey. Roller Compacted concrete Dams:121-126

8. Bellezza I, Fratalocchi E (2006) Effectiveness of cement on hydraulic conductivity of compacted soilcement mixtures. Proceedings of the Institution of Civil Engineers-Ground Improvement 10 (2):77-90. doi:https://doi.org/10.1680/grim.2006.10.2.77

9. Cai X, Wu Y, Guo X, Ming Y (2012) Research review of the cement sand and gravel (CSG) dam. Frontiers of Structural Civil Engineering 6(1):19-24. doi:https://doi.org/10.1007/s11709-012-0145-y

10. Choobbasti AJ, Kutanaei SS (2017) Microstructure characteristics of cement-stabilized sandy soil using nanosilica. J Rock Mech Geotech Eng 9(5):981-988. doi:https://doi.org/10.1016/j.jrmge.2017.03.015

11. Chrysochoou M (2014) Investigation of the mineral dissolution rate and strength development in stabilized soils using quantitative X-ray diffraction. Journal of materials in civil engineering 26(2):288295. doi:https://doi.org/10.1061/(ASCE)MT.1943-5533.0000814

Page 21/29 
12. Gouvas H, Orfanos C (2014) Determination of factors affecting compressive strength of lean RCC mixtures: The experience of Filiatrinos Dam. Geotech Geol Eng 32(5):1317-1327. doi:https://doi.org/10.1007/s10706-014-9807-y

13. GUILLEMOT T, LINO M (2012) Design and Construction Advantages of Hardfill Symmetrical Dams-Case Study: SafSaf Dam In Eastern Algeria. Zaragoza 23:25

14. Jamshidi RJ, Lake CB (2015) Hydraulic and strength properties of unexposed and freeze-thaw exposed cement-stabilized soils. Can Geotech J 52(3):283-294. doi:https://doi.org/10.1139/cgj-2014-0100

15. Jia J, Ding L, Wu Y, Li A, Li S Building Cemented Material Dam with Soft Rock Material. In: The International Conference on Embankment Dams (2020) Springer, pp 27-35. doi:https://doi.org/10.1007/978-3-030-46351-9_3

16. Jia J, Lino M, Jin F, Zheng C (2016) The cemented material dam: a new, environmentally friendly type of dam. Engineering 2(4):490-497. doi:https://doi.org/10.1016/J.ENG.2016.04.003

17. Lake CB, Yousif MA-M, Jamshidi RJ (2017) Examining freeze/thaw effects on performance and morphology of a lightly cemented soil. Cold Reg Sci Technol 134:33-44. doi:https://doi.org/10.1016/j.coldregions.2016.11.006

18. Londe P, Lino M (1992) The faced symmetrical hardfill dam: a new concept for RCC. International water power dam construction 44(2):19-24

19. Mahasneh BZ, Shawabkeh RA (2004) Compressive strength and permeability of sand-cement-clay composite and application for heavy metals stabilization. American Journal of Applied Sciences 1:1-4

20. Mohamedzein YE-A, Al-Rawas AA (2011) Cement-stabilization of sabkha soils from Al-Auzayba, Sultanate of Oman. Geotech Geol Eng 29(6):999

21. Moon DH, Grubb DG, Reilly TL (2009) Stabilization/solidification of selenium-impacted soils using Portland cement and cement kiln dust. J Hazard Mater 168(2-3):944-951. doi:https://doi.org/10.1016/j.jhazmat.2009.02.125

22. Preetham H, Nayak S (2019) Geotechnical investigations on marine clay stabilized using granulated blast furnace slag and cement. International Journal of Geosynthetics Ground Engineering 5(4):28. doi:https://doi.org/10.1007/s40891-019-0179-5

23. Reddy BV, Kumar PP (2011) Cement stabilised rammed earth. Part A: compaction characteristics and physical properties of compacted cement stabilised soils. Materials structures 44(3):681-693

24. Shuttoh K (1983) Basic studies on plastic concrete (CBC) for cut off wall. J of Concrete Engrg 21(11):4960

25. Tabet WE, Cerato AB, Elwood Madden AS, Jentoft RE (2018) Characterization of Hydration Products' Formation and Strength Development in Cement-Stabilized Kaolinite Using TG and XRD. J Mater Civ Eng 30(10):04018261. doi:https://doi.org/10.1061/(ASCE)MT.1943-5533.0002454

26. Wu P, Molenaar A, Houben IL (2011) Cement-bound road base materials. Submitted to Delft University of Technology, Delft

27. Yanmaz AM, Sezgin OI (2009) Evaluation study on the instrumentation system of Cindere dam. Journal of performance of constructed facilities 23(6):415-422. doi:https://doi.org/10.1061/(ASCE)CF.19435509.0000051 
28. Yokotsuka T (2000) Application of CSG method to construction of gravity dam. ICOLD 2000 at Beijing 4 (14)

29. Yongfeng D, Songyu L, Jian'an H, Kan L, Yanjun D, Fei J (2012) Strength and permeability of cemented soil with PAM. In: Grouting and deep mixing 2012. pp 1800-1807.

doi:https://doi.org/10.1061/9780784412350.0155

30. Yu Y, Pu J, Ugai K (1997) Study of mechanical properties of soil-cement mixture for a cutoff wall. Soils foundations 37(4):93-103. doi:https://doi.org/10.3208/sandf.37.4_93

31. Yu Y, Pu J, Ugai K, Hara T (1999) A study on the permeability of soil-cement mixture. Soils foundations 39(5):145-149. doi:https://doi.org/10.3208/sandf.39.5_145

\section{Figures}

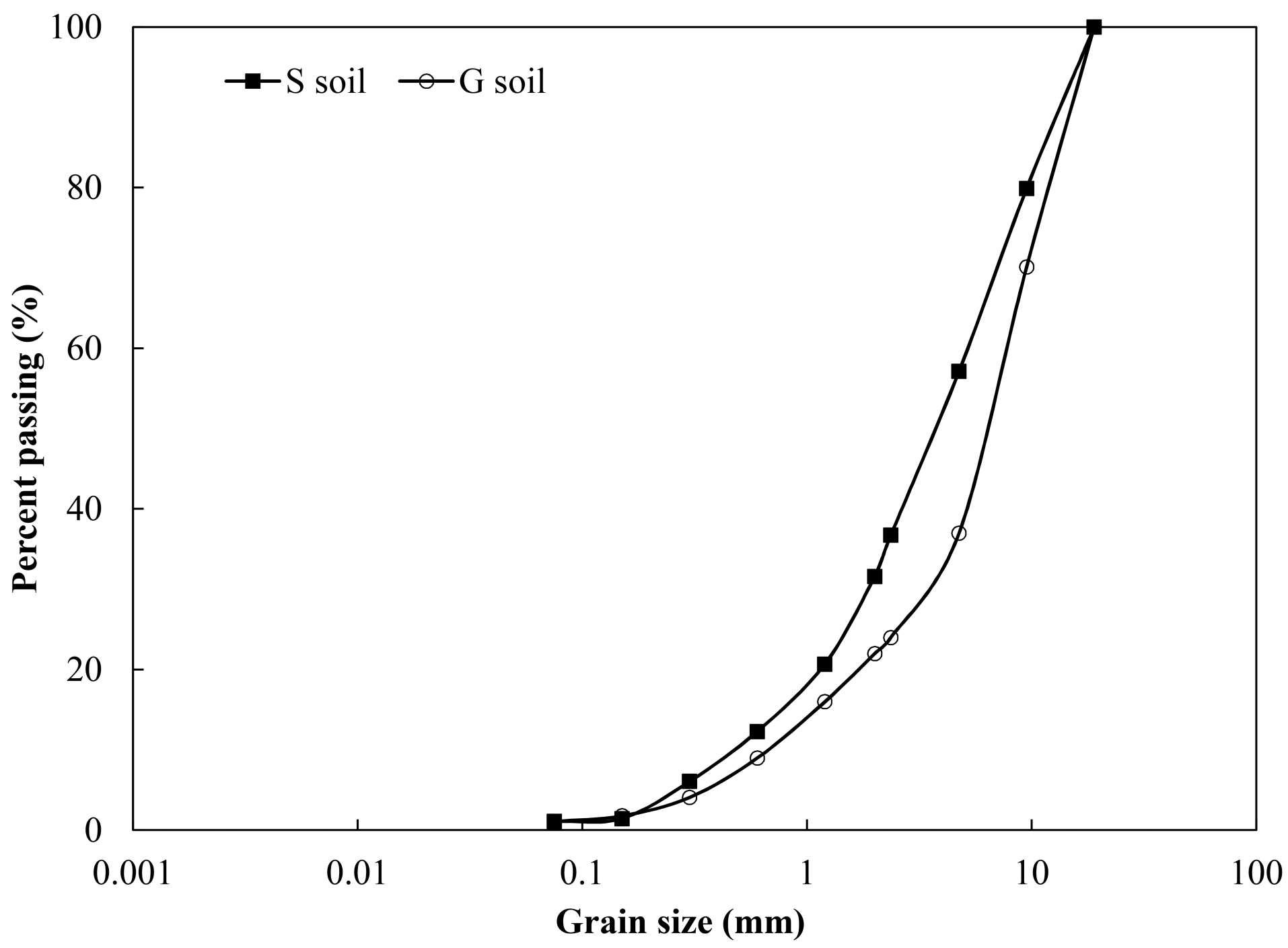

Figure 1

The grains size distribution of native soils 


\section{Figure 2}

The density-moisture graph of compaction test for cemented sand mixtures with $5 \%$ cement and containing a) no fine additive, b) bentonite additive, c) kaolinite additive
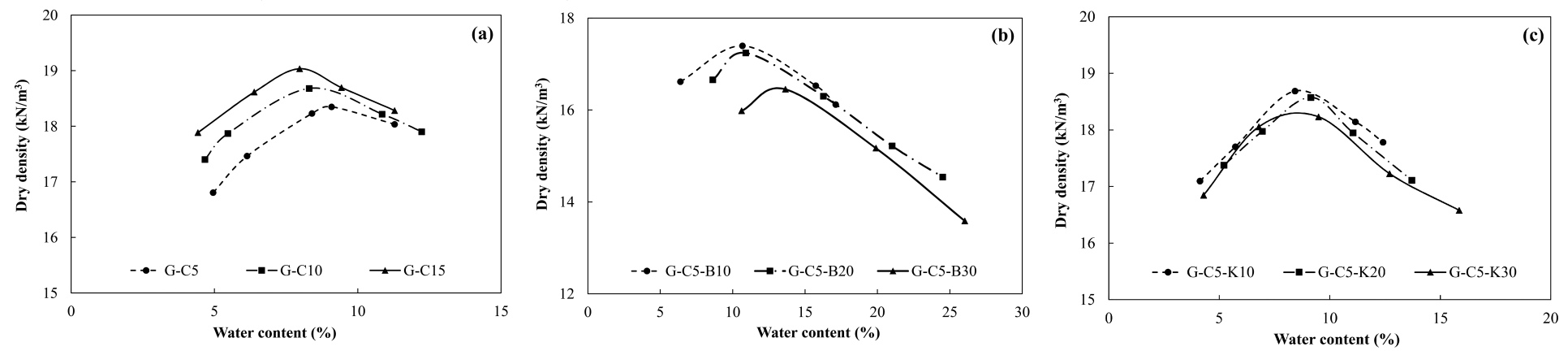

Figure 3

The density-moisture graph of compaction test for cemented gravel mixtures with $5 \%$ cement and containing a) no fine additive, b) bentonite additive, $c$ ) kaolinite additive 

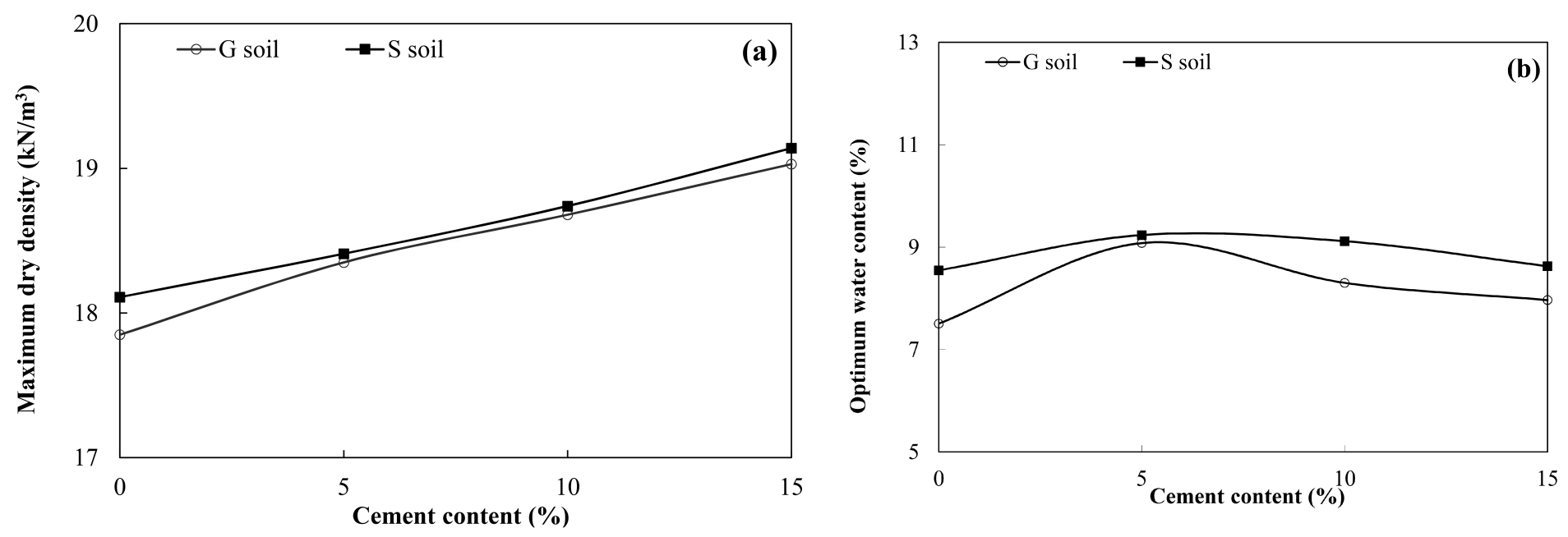

\section{Figure 4}

The graphs of maximum dry density and optimum water content for both cemented sand mixtures and cemented gravel mixtures with different cement contents and without fine additive

\section{Figure 5}

The graphs of maximum dry density and optimum water content versus bentonite content for the cemented sand mixtures containing bentonite additive
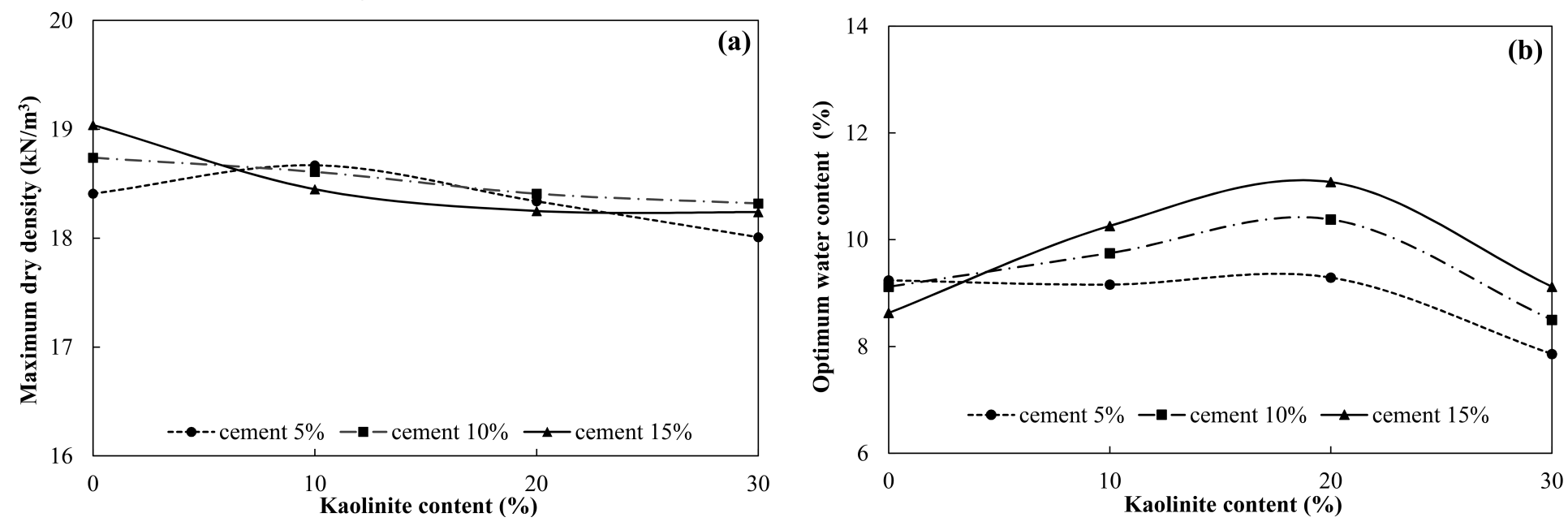
Figure 6

The graphs of maximum dry density and optimum water content versus kaolinite content for the cemented sand mixtures containing kaolinite additive

20

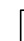

(a)

16

(h)

\section{Figure 7}

The graphs of maximum dry density and optimum water content versus bentonite content for the cemented gravel mixtures containing bentonite additive

\section{Figure 8}

The graph of maximum dry density and optimum water content versus kaolinite content for the cemented gravel mixtures containing kaolinite additive 
15

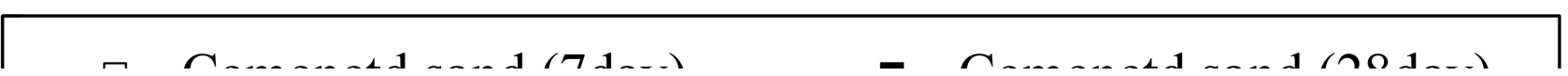

\section{Figure 9}

The graph of uniaxial compressive strength versus cement content for cemented sand mixtures (continuous line) and cemented gravel mixtures (dashed line) which have no fine additive and cured at the ages of 7 and 28 days

\section{Figure 10}

The graph of uniaxial compressive strength for cemented sand mixtures cured at ages of 7 and 28 days and containing: a) bentonite additive, b) kaolinite additive 


\section{Figure 11}

The graph of uniaxial compressive strength for cemented gravel mixtures cured at ages of 7 and 28 days and containing: a) bentonite additive, b) kaolinite additive

\section{Figure 12}

The graph of permeability for cemented sand mixtures cured at ages of 14 and 28 days and containing: a) bentonite additive, b) kaolinite additive
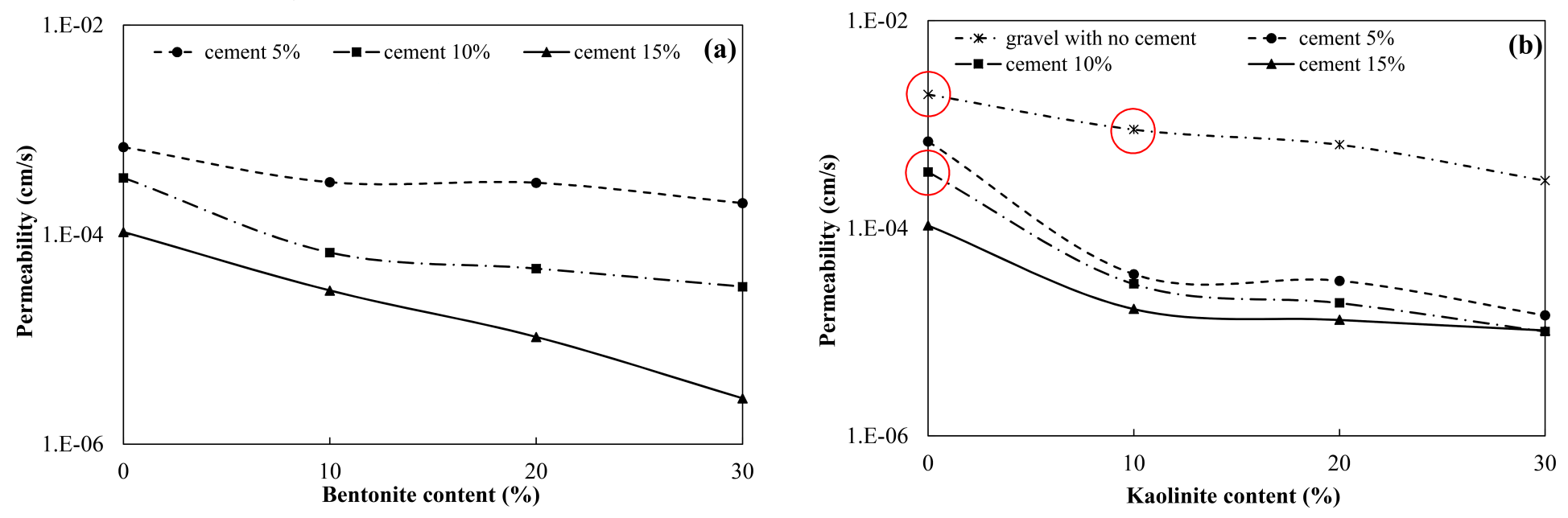

\section{Figure 13}

The graph of permeability for cemented gravel mixtures cured at age of 28 days and containing: a) bentonite additive, b) kaolinite additive

\section{Figure 14}

The SEM images of cemented sand mixtures with cement of $5 \%$ and different fine additive under $500 x$ magnification: a) S-C5 mixture, b) S-C5-B10 mixture, c) S-C5-K10 mixture, d) S-C5-B30 mixture, e) S-C5-K30 
mixture

Page 29/29 